NBER WORKING PAPER SERIES

\title{
STUDENT AID SIMPLIFICATION: LOOKING BACK AND LOOKING AHEAD
}

\author{
Susan Dynarski \\ Mark Wiederspan \\ Working Paper 17834 \\ http://www.nber.org/papers/w17834 \\ NATIONAL BUREAU OF ECONOMIC RESEARCH \\ 1050 Massachusetts Avenue \\ Cambridge, MA 02138 \\ February 2012
}

We thank Monica Bhatt and Dyuti Bhattacharya for excellent research assistance. Judith Scott-Clayton provided helpful comments. Edward Pacchetti and Thomas Weko of the US Department of Education kindly provided statistics on FAFSA submissions. Dynarski benefited from thoughtful conversations with members of the Rethinking Student Aid Task Force. All errors and opinions are our own. The views expressed herein are those of the authors and do not necessarily reflect the views of the National Bureau of Economic Research.

NBER working papers are circulated for discussion and comment purposes. They have not been peerreviewed or been subject to the review by the NBER Board of Directors that accompanies official NBER publications.

(C) 2012 by Susan Dynarski and Mark Wiederspan. All rights reserved. Short sections of text, not to exceed two paragraphs, may be quoted without explicit permission provided that full credit, including (C) notice, is given to the source. 
Student Aid Simplification: Looking Back and Looking Ahead

Susan Dynarski and Mark Wiederspan

NBER Working Paper No. 17834

February 2012

JEL No. I22,I28

\begin{abstract}
$\underline{\text { ABSTRACT }}$
Each year, fourteen million households seeking federal aid for college complete a detailed questionnaire about their finances, the Free Application for Federal Student Aid (FAFSA). At 116 questions, the FAFSA is almost as long as IRS Form 1040 and substantially longer than Forms 1040EZ and 1040A. Aid for college is intended to increase college attendance by reducing its price and loosening liquidity constraints. Economic theory, empirical evidence and common sense suggest that complexity in aid could undermine its ability to affect schooling decisions. In 2006, Dynarski and Scott-Clayton published an analysis of complexity in the aid system that generated considerable discussion in academic and policy circles. Over the next few years, complexity in the aid system drew the attention of the media, advocacy groups, presidential candidates, the National Economic Council and the Council of Economic Advisers. A flurry of legislative and agency activity followed. In this article, we provide a five-year retrospective of what has changed in the aid application process, what has not, and the possibilities for future reform.
\end{abstract}

Susan Dynarski

University of Michigan

Weill Hall

735 South State Street

Ann Arbor, MI 48109-3091

and NBER

dynarski@umich.edu

Mark Wiederspan

University of Michigan

School of Education

610 East University Avenue

Ann Arbor, Michigan 48109-1259

mwieders@umich.edu 


\section{Introduction}

Each year, 14 million households seeking federal aid for college complete a detailed questionnaire about their finances, the Free Application for Federal Student Aid (FAFSA). With 116 questions, the FAFSA is almost as long as IRS Form 1040 and substantially longer than Forms 1040EZ and 1040A. Since the majority of households use the shorter IRS forms, the typical household's aid application is longer and more complicated than its federal tax return. Aid for college is intended to increase college attendance by reducing its price and loosening liquidity constraints. Economic theory, empirical evidence and common sense suggest that complexity in aid could undermine its ability to affect schooling decisions.

A long-standing theoretical and experimental literature suggests that seemingly minor differences in program design can have profound impacts upon decision-making (Kahneman and Tversky, 2000). A burgeoning empirical literature has demonstrated that these predictions hold in real-life situations such as saving for retirement (Madrian and Shea, 2001). Empirical patterns in the behavioral impact of aid have supported the hypothesis that complexity in the aid system undermines its efficacy: simple aid pro- grams have a robust impact on college attendance, while traditional forms of student aid (which require a FAFSA) do not (Dynarski and Scott-Clayton, 2006). A recent field experiment directly tested this hypothesis by randomly assigning families to a radically simplified aid application process (Bettinger et al., forthcoming). The results were striking: a simplified aid application process produced a substantial increase in college attendance, comparable to that induced by offering an applicant several thousand dollars in grant aid. Based on these results and a review of other interventions intended to increase college 
attendance, Dynarski, Hyman, and Schanzenbach (2011) calculate that simplifying the aid process is (by several orders of magnitude) the cheapest way to increase college attendance.

Five years ago, Dynarski and Scott-Clayton (2006) published an analysis of complexity in the aid system that generated considerable discussion in academic and policy circles. Over the next few years, complexity in the aid system drew the attention of the media, advocacy groups, presidential candidates, the National Economic Council, and the Council of Economic Advisers. A flurry of legislative and agency activity around aid simplification followed. In this article, we provide a retrospective of what has changed in the aid application process, what has not, and the possibilities for future reform.

\section{Background: A Brief Overview of Aid for College}

In this section we briefly describe how the financial aid system functions in the United States and how it evolved into its current shape. ${ }^{1}$ Two programs represent the bulk of federal aid to college students: the Pell Grant and the Stafford Loan. Both are distributed through the "needdetermination” process, in which extensive data about a student's resources and expenses are used to estimate his or her "need" for aid. The FAFSA is required for all federal grants and loans. Most state aid and school scholarships also require the FAFSA. Some colleges require an additional aid application. The FAFSA collects basic demographics (e.g., name, social security number, citizenship, date of birth) as well as detailed information about the student's and parents' income, assets, and expenditures.

Once the FAFSA is submitted, the U.S. Department of Education (ED) computes the Expected Family Contribution (EFC), an estimate of how much the family can pay out of pocket

\footnotetext{
${ }^{1}$ Some of this material is drawn from Dynarski and Scott-Clayton (2006), where this topic is covered in greater detail.
} 
for college. "Need" is defined as the difference between the cost of attendance (e.g., tuition, fees, books, and living expenses) and this family contribution. Using the EFC, colleges personalize a package of grants and loans for each student, which they then mail out in award letters, typically in March and April. Only upon receiving these award letters do students know how much college will cost for the upcoming academic school year.

The current aid application has its historical roots in a form developed by a group of private colleges in the Fifties. The colleges, under the auspices of the College Board, worked together to establish a common method for assigning aid so that they could prevent competitive bidding for students. They established a common aid application (the Parents' Confidential Statement) and formed the College Scholarship Service (CSS) to process the application (Duffy and Goldberg, 1998; Wilkinson, 2005). The form was intended to measure income and wealth at quite high levels, reflecting the student composition of the founding colleges (e.g., Harvard). The form asked, for example, about the model of the family car. At the time that this first aid form was designed, there was no federal aid application to work from, since the Pell Grant and student loan programs had yet to be created. The private institutions were the first architects of aid in the US, and their imprint is clear in the current system.

In 1973, the most ambitious aid program was established: the federal Pell Grant, first known as the Basic Education Opportunity Grant (BEOG). The Pell was introduced in a context of small, scattered state and institutional aid programs, which often had their own applications. Concerned about the multiple forms faced by students seeking aid for college, a group of financial aid stakeholders came together in 1975 as the National Task Force on Student Aid Programs, or the Keppel Task Force. The group succeeded in getting cooperation from institutions, states and the federal government in the development of a common application for 
student aid. A common aid application need not have implied a common formula for defining a student's aid eligibility, any more than the Common Application now used by 456 colleges defines a single standard for college admission. ${ }^{2}$ However, as part of the initiative that created the common form, the various players also agreed upon a common formula, initially known as the Uniform Methodology and now known as the Federal Methodology.

The model established in 1975 persists today: a common application for collecting extensive data about a student's finances (the FAFSA) linked to a common formula (the Federal Methodology) for translating these data into a metric of a student's ability to pay (the Expected Family Contribution). Federal, state and institutional aid programs use the EFC to determine aid eligibility.

The contents of the FAFSA and the definition of the EFC are controlled by the federal government. In its periodic reauthorizations of the 1965 Higher Education Act, Congress makes decisions about aid, which are then implemented by ED. ED has considerable discretion in its implementation of Congressional intent. ED's decisions about how to implement a given directive can add complexity to the aid process. For example, in 2008, Congress directed ED to allow homeless applicants to complete a shortened application. In response, ED added three questions to the FAFSA that elicit whether a student has been defined as homeless by a list of state and local agencies. This is a case in which a Congressional directive to simplify the process for a minority of applicants led to an increase in complexity for all applicants.

\footnotetext{
${ }^{2}$ A list of colleges using the Common Application can be found at http://www.commonapp.org.
} 


\section{Complexity in the Aid System: Critiques and Responses}

In 2005, the Advisory Committee on Student Financial Assistance, a Congressionally authorized standing committee, released a report that critiqued complexity in the financial aid system (Advisory Committee on Student Financial Assistance, 2005). The committee concluded that:

Millions of students and adult learners who aspire to college are overwhelmed by the complexity of student aid. Uncertainty and confusion robs them of its significant benefits. Rather than promote access, student aid often creates a series of barriers - a gauntlet that the poorest students must run to get to college.

Dynarski and Scott-Clayton (2006) quantified complexity in the aid system. That article showed that the FAFSA rivals the IRS tax forms in length, with more questions than the 1040EZ, 1040A or even the 1040. That article also demonstrated that there is very little tradeoff between simplicity and targeting in the federal aid programs, since the majority of questions on the FAFSA have little marginal impact on federal aid eligibility. A small handful of the questions in particular, income and family size — account for about 80 percent of the variation in Pell grant eligibility. Most of the questions could therefore be removed from the FAFSA while maintaining the existing distribution of aid.

This research was cited in the 2006 report of the Commission on the Future of Higher Education, which had been charged by then-Secretary of Education Margaret Spellings to identify challenges facing the higher education system in the United States. The Commission called for "consolidating programs, streamlining processes, and replacing the FAFSA with a much shorter and simpler application (Commission on the Future of Higher Education, 2006, p. 3).” The analysis of Dynarski and Scott-Clayton (2006) was developed into a policy proposal to streamline the aid application process and released by the Hamilton Project in 2007 (Dynarski and Scott-Clayton, 2007). Elements of this proposal were integrated into the platforms of several of the presidential candidates, including that of Barack Obama, and ultimately were included in 
the Democratic national platform. In 2008, a working group of academics and aid officials released a report sounding similar themes under the auspices of the College Board (Rethinking Student Aid Study Group, 2008).

In 2007, Congress responded to the rising chorus of criticism of the aid application by including several simplifications in the College Cost Reduction and Access Act (CCRAA). These provisions did not take effect until the 2009-10 academic year. CCRAA eliminated portions of the FAFSA, including Worksheet A, which had asked about untaxed income. But CCRAA also imposed new requirements for determining if a student was an independent, thereby adding questions to the FAFSA. CCRAA also expanded the number of students who automatically qualified for a family contribution of zero (an “auto-zero EFC”). Before CCRAA, households with annual income below $\$ 20,000$ were eligible for the auto-zero EFC; CCRAA raised that threshold to $\$ 30,000$ (U.S. Department of Education, 2008a).

Upon Barack Obama's election, ED, the National Economic Council and the Council of Economic Advisers began working on efforts to streamline the aid process, releasing in September 2009 a report devoted to the topic (Council of Economic Advisors, 2009) that drew extensively upon Dynarski and Scott-Clayton (2006), Dynarski and Scott-Clayton (2007) and the report of the Rethinking Student Aid Study Group (2008). During the summer of 2009, Congressional committees developed ambitious legislation to streamline the aid form. Most of these provisions were eventually discarded in last-minute negotiations, which were dominated by legislation to overhaul student loans and health care.

Since this burst of Congressional activity, the most significant changes to the aid system have been made via administrative authority. ED has worked to simplify the online FAFSA, eliminating repetitive questions (e.g., applicants had previously been asked for their age as well 
as their birth date) and introducing "skip logic" that allows students and parents to answer fewer questions based on their responses to screening questions (U.S. Department of Education, 2010). In the spring of 2010, some online applicants were for the first time allowed to automatically transfer their IRS data into the FAFSA application. This process saves applicants from having to collect tax documents and enter items manually. This in turn prevents data-entry errors, which cause applications to be flagged for revision and resubmission. ${ }^{3}$ This represented a major administrative breakthrough, since IRS had steadfastly refused to allow any such connection of data from the two agencies, citing both privacy concerns and a longstanding resistance to using tax data for any purpose other than tax collection. Both of these issues were resolved to IRS's satisfaction by having applicants personally log into IRS servers while filling in the FAFSA, with data items then copied over to the aid form via the applicant's web browser.

This effort to streamline the online application was paired with an ongoing campaign to move applicants away from the paper FAFSA. ED stopped accepting bulk orders for the paper FAFSA, which had been placed annually by colleges, high schools, college coaching programs, libraries, and community agencies. This meant, for example, that students were no longer able to go to their high school guidance counselor to get a copy of the FAFSA, but had to instead order one from ED. Paper applications dropped sharply, from 696,000 filed by undergraduates in 2006-07 to 500,000 the following year (U.S. Department of Education, 2008b, 2009a). In 200910, only 94,000 paper FAFSA applications were submitted (U.S. Department of Education, 2011a).

In another important development, completing the FAFSA online (but not on paper) now produces an immediate estimate of federal aid eligibility, just as completing a 1040 produces an

\footnotetext{
${ }^{3}$ ED has for a number of years sent FAFSAs to IRS to have them checked for errors in income and tax data. Upon discovering an inconsistency, IRS flags the application, which ED then returns to the applicant for revision. IRS does not specify (to ED or the applicant) which answer is in error.
} 
estimate of tax liability. Previously, applicants received no notification of aid eligibility until they received an award letter from the aid offices of the colleges to which they had been admitted.

\section{What Has Changed? What Has Not Changed?}

We have just described quite a bit of legislative and agency activity. What has been the net effect on the applicant experience? Is applying for aid less of a hurdle than it was in 2006?

\section{A. FAFSA Still Longer than Typical Federal Tax Return}

The FAFSA still makes the typical tax return look svelte. While two dozen questions have been removed from the FAFSA in the past five years, another dozen have been added. As a result, the FAFSA now has 116 questions, compared to 127 questions five years ago. ${ }^{4}$ In Table 1, we compare the 2011-12 FAFSA to its 2006-07 incarnation, as well as to the 1040, 1040A and 1040EZ for the 2010 tax year. The FAFSA is now slightly shorter than the 1040, at 116 and 126 questions, respectively. In 2006, by contrast, the FAFSA was slightly longer. Since more than half of families with incomes in the Pell range (that is, below $\$ 50,000$ ) fill out the $1040 \mathrm{~A}$ or $1040 \mathrm{EZ},{ }^{5}$ the shorter tax forms may be a more appropriate benchmark. The FAFSA compares poorly with these shorter IRS forms: the 1040EZ has 38 questions and the 1040A has 84, compared to the FAFSA's 116. Nine data items on the 1040EZ (44 on the 1040A) are used to

\footnotetext{
${ }^{4}$ Dropped questions include eight pertaining to earned income credits, additional child tax credits, welfare benefits, and untaxed social security benefits, two relating to veteran benefits, four pertaining to untaxed income and income adjustments, six calculation lines, one on planned enrollment intensity and two about the colleges to which the FAFSA is being forwarded. Added questions address tax credits and allowances (four questions), dependency status (six questions), the student's high school name and location, parents' email address, dislocated-worker status, and means-tested benefits.

${ }^{5}$ Authors' calculations using published tables in Parisi (2011).
} 
compute tax liability, as compared to the 66 FAFSA questions used to compute aid eligibility. As was true in 2006, it is a puzzle why the aid system requires so much more data than the tax system to determine ability to pay.

\section{B. Official Estimate of Time to Complete FAFSA Still Implausibly Low}

As can be seen in Table 2, ED has increased its estimate of time needed to complete the paper FAFSA, from one hour to three hours:

The time required to complete the paper or PDF version of the FAFSA is estimated to be three hours; the time required to complete the web version of the FAFSA, on FAFSA on the Web, is estimated to be one hour and fifteen minutes; the time required to complete the pre-filled web version of the FAFSA, on FAFSA on the Web, is estimated to be fiftyfive minutes. These estimates include the time necessary to review instructions, search data resources, gather the data needed, and complete and review the information collection, and make copies of output documents for future reference. ${ }^{6}$

ED was roundly criticized for the implausibility of its earlier estimates, and these new, higher estimates still seem low. The Paperwork Reduction Act of 1995, which mandates these time estimates, allows each agency to choose its own method for calculating the time costs of filling out federal forms, and we know of no detailed exposition of the process ED uses to generate these estimates. The online FAFSA consists of 19 screens, 116 questions and many pages of accompanying instructions. ED calculates that online FAFSA applicants spend 23 minutes logged in and completing the form (U.S. Department of Education, 2011b). Given their overall estimate of 75 minutes, this indicates ED has concluded that applicants can read the FAFSA instructions and gather the requisite financial documentation (including that of spouses or parents) in 52 minutes.

\footnotetext{
${ }^{6}$ 2012-13 FAFSA instructions, downloaded on January 2, 2012 from http://studentaid.ed.gov.
} 
These figures look particularly implausible when compared to the paperwork estimates of the IRS. The IRS estimates that it takes seven hours to complete the 1040EZ, which is a third the length of the FAFSA. The IRS estimates it takes 23 hours to complete the 1040, which is slightly longer than the FAFSA. Outside researchers who have fielded taxpayer surveys have concluded that even these IRS estimates are low (Blumenthal and Slemrod, 1992). No independent researchers have conducted a similar survey or observation of how long it takes to complete the FAFSA, whether on paper or online. The time is ripe for such a study.

\section{Most Applicants Can't Use FAFSA-IRS Link}

The ability of an applicant to link data from his 1040 to his FAFSA has great potential to simplify the application process. Much of the financial data needed to compute aid eligibility is present in the IRS data, as are many of the demographic items that the FAFSA requests. As discussed in Dynarski and Scott-Clayton (2006) and Dynarski and Scott-Clayton (2007), it is feasible to eliminate the FAFSA completely, with tax data alone used to calculate eligibility.

As implemented, however, the IRS link falls well short of this potential. Applicants are allowed to import their IRS data only if they have already filed their tax return for the previous tax year. IRS also needs to have made these newly filed returns available to online aid applicants, which takes two to eight additional weeks after the return is filed. Given these constraints, it is virtually impossible for anyone filing under the traditional academic and tax schedules to use the FAFSA-IRS link. A family who files a 1040 as soon as W-2s are due in household mailboxes (start of February) would be eligible to use the FAFSA-IRS link sometime between midFebruary and April, while a family who files on tax day would not be able to do so until May or 
June. As can be seen in Figure 1, most aid applicants have submitted the FAFSA well before these dates.

Why do so many aid applicants file early in the year? Because schools and aid programs tell them to. Colleges ask students to file FAFSAs early in the year, as do state aid programs, whose deadlines are listed on the FAFSA. By mid-April, the date by which an early tax filer could plausibly use the FAFSA-IRS link, the filing deadline has passed for fifteen state aid programs, including those in California (March 2) and Illinois ("as soon as possible after January 1”). Students who want to qualify for state aid need to file even earlier than these posted deadlines (Steinberg, 2011), since some programs give out funds on a first-come, first-served basis, with eligible candidates left empty-handed once funds are depleted. In an analysis of Kentucky's College Access Program Grant, we found that roughly 40 percent of eligible applicants received no grant because funds ran out before the filing deadline. A student who wants to maximize her chances of receiving aid would therefore file early, forgo the IRS match and manually enter her tax information. And this, indeed, is what has occurred. ED estimates that just 24 percent of applicants use the IRS link (U.S. Department of Education, 2011b).

\section{Pell Has Grown More Generous and Spending Has Risen Rapidly}

While aid simplification has moved forward at a halting pace, spending on the Pell grant program has exploded (see Figure 2). Pell spending grew by \$15 billion between 2007-08 and 2009-10 and was estimated to grow by another $\$ 5$ billion by the end of the 2010-11 academic year (College Board, 2011). This rapid growth is driven by two factors: a rise in the number of students attending college and an increase in the generosity of the program. The student 
population has grown both due to a demographic blip in the college-age population (Institute of Education Sciences, 2011) and a persistently weak labor market.

The average Pell has risen sharply; this can occur because the marginal recipient is more needy or because the program has grown more generous. As we now show, the latter explanation is the most important one. In Table 2, we take full-time, undergraduate aid applicants in the 2007-08 National Postsecondary Student Aid Survey and run their characteristics through the aid formulas for academic years 2003-04, 2007-08, 2009-10 and 2011-12. ${ }^{7}$ This analysis effectively holds constant student characteristics (income, schooling costs, etc.) while allowing the aid formula to vary. The average Pell for this sample of students rose from $\$ 1,417$ in 200304 to $\$ 1,673$ in $2007-08$, an increase of $\$ 256$, or 18 percent. The increase between $2007-08$ and 2011-12 will be considerably larger. Using the 2011-12 Pell formula, we calculate an average Pell for this sample of students of $\$ 2,692$, which is 60 percent $(\$ 1,019)$ more than these students received under the 2007-08 Pell formula. Nearly 60 percent of the students in the sample receive an increase of at least \$500 under the 2011-12 formula, relative to the 2007-08 formula. These substantial increases in generosity account for $\$ 4.9$ billion of the increase in Pell spending between 2007-08 and 2011-12.

The increasing generosity of the Pell is largely driven by a rising "Pell maximum" (the grant that goes to students with an EFC of zero) paired with an expansion in the share of students who automatically qualify for this maximum. The Pell maximum rose from $\$ 4,050$ in 2003-04 to $\$ 5,550$ in 2011-12. ${ }^{8}$ The income ceiling on automatic qualification for the Pell maximum has doubled, from $\$ 15,000$ in $2003-04$ to $\$ 31,000$ in 2011-12. Further, any household headed by a

\footnotetext{
${ }^{7}$ More details about the NPSAS are provided in the Empirical Methodology section and the Data Appendix.

${ }^{8}$ These are the Pell maxima for full-time enrollment. Part-time students receive pro-rated grants.
} 
dislocated worker, or that receives a means-tested benefit in the previous two years, now qualifies for an auto-zero EFC and, thereby, the Pell maximum.

We graphically depict these changes in the generosity of the Pell in Figure 3. The sample again is full-time, undergraduate aid applicants in 2007-08. We calculate aid eligibility using the aid formulas for 2003-04, 2007-08, 2009-10 and 2011-12 and then plot the average values by income. The increasing generosity of the Pell is indicated by the rising intercept of the relationship between income and the Pell. There is a particularly sharp jump between 2007-08 and 2009-10, when the Pell maximum rose by $\$ 1,040$ (see Table 2). This increase in the Pell maximum did not only benefit the most needy students, but also increased Pell grants throughout the income distribution. This can be seen more clearly in Figure 4, which shows the Pell averages by income in 2007-08 (light bars) and the change in these averages by 2011-12 (dark bar).

These figures and calculations are not intended to demonstrate that the average Pell is now "too big." Rather, our point here is that drastic change has occurred in the generosity of the Pell program, which throws into even sharper relief the halting progress in reducing the program's complexity. As we will show below, a radical simplification of the aid application process would cost only a fraction of what has been recently been spent by increasing the Pell maximum and the auto-zero EFC.

It is also important to note that the new value of the Pell looks a lot less generous when viewed in historical context (Figure 2). The inflation-adjusted value of the maximum Pell, which had eroded over time, has now returned to its level when the program was established in the midSeventies. Even with this increase, the maximum Pell has less purchasing power than it did in the 
mid-Seventies, since tuition prices have risen much faster than inflation over the past few decades.

\section{E. What Could Be Changed?}

We have described the evolution of complexity in the aid system and recent efforts to reduce it. What are the possibilities for change going forward? Dynarski and Scott-Clayton (2006) showed, based on 2003-04 data, that the aid system could be massively simplified without compromising targeting in the Pell. Does this finding still hold? In this section we update the analysis of Dynarski and Scott-Clayton (2006) using 2007-08 data on student aid and aid applications. We estimate the marginal contribution of each FAFSA question to variation in Pell eligibility. We show that the vast majority of questions still have little impact on aid eligibility and could be eliminated with very little effect on the distribution of aid. We also examine the effect of using the previous tax year's 1040 data in the calculation of aid. If ED were willing to use the previous year's tax return to calculate aid eligibility, then all applicants could take advantage of the IRSFAFSA link, thereby considerably streamlining the application process.

\section{A. Empirical Methodology}

Using data from the nationally representative 2007-08 National Postsecondary Student Aid Survey (NPSAS) (U.S. Department of Education, 2009b), we examine the relationship between federal aid received and information in the FAFSA. ${ }^{9}$ We focus on Pell Grants, since they are the most expensive component of federal need-based aid. Our sample consists of 35,000 dependent and independent undergraduates who attended college full-time for the full-year in 2007-08 and

\footnotetext{
${ }^{9}$ This description of the methodology used in the analysis is drawn from Dynarski and Scott-Clayton (2006).
} 
who applied for federal aid (more details are provided in the Data Appendix). The NPSAS sampling weights indicate that these observations represent about 5 million college students.

We first use the NPSAS to replicate the current distribution of aid. We calculate aid using the federal financial aid formula and compare these calculated aid amounts with their true values, which are given in the NPSAS. Our calculations of Pell Grants and EFCs are extremely close to their true values. Regressing the actual against the predicted values yields an $\mathrm{R}^{2}$ of 0.94 for the EFC and 0.84 for the Pell. ${ }^{10}$ These predicted values constitute the baseline against which we compare aid under various alternative simplification scenarios.

To measure the influence of the various data elements on aid, we sequentially exclude data items from the aid formula and recalculate aid, and then compare the new estimates to the baseline values whose calculation is described above. Mechanically, this is achieved by setting the value of the excluded items to zero (or, sometimes, to their mean). We measure the predictive power of these simulations with the $\mathrm{R}^{2}$ from regressions of the baseline aid values against their simulated values under simplification. We also plot average gains and losses against income.

\section{B. Using Fewer Data Items to Determine Aid Eligibility}

We start by throwing out all of the data used in the aid calculation except for items available on the IRS Form 1040. This opens the door to an application-free Pell, since eligibility could be calculated using IRS data alone. With this approach, we determine Pell amounts using the adjusted gross income of the parents and students, taxes paid, state of residence, family size, parents' and independent students' marital status, type of income tax form filed, and number of family members in college.

\footnotetext{
${ }^{10}$ Unlike Dynarski and Scott-Clayton (2006) we do not exclude observations for which we cannot replicate the Pell or EFC within $\$ 1,000$, even using all of the data and the exact federal aid formula. As a result, the $\mathrm{R}^{2}$ in these baseline regressions is slightly lower than in their tables.
} 
The extensive data we drop in this simulation explain only ten percent of the variation in aid (Column 2, Table 3). With the few variables we include, we explain 89.6 percent of the variation in the Pell Grant. Our simulated Pell is within \$100 of the baseline Pell (which we estimated using all of the items in the aid formula) for 78 percent of students, and within $\$ 500$ of baseline for 88 percent of students. For 73 percent of FAFSA applicants, and half of current Pell recipients, the Pell does not change by even a dollar.

The changes in the distribution of the Pell resulting from this massive simplification of the aid form are depicted in Figure 5, where we plot average Pell against adjusted gross income. The light bars depict the average Pell for each income group, using the complete aid formula. The dark bars represent the change in the average Pell for each income group that results from using only IRS data to estimate aid eligibility. As is clear from the figure, the changes are extremely small. The average Pell for this population rises by $\$ 73$ from a baseline of $\$ 1,673$, or 4.4 percent. We estimate that overall Pell spending would rise by about $\$ 300$ million for this population. These numbers are dwarfed by the increasing generosity of the Pell: as we showed earlier, recent changes in Pell generosity have boosted the average Pell by 60 percent, resulting in an increase in overall Pell spending of nearly $\$ 5$ billion.

\section{Use Prior Year's 1040 to Determine Aid Eligibility}

All applicants, rather than just 24 percent, could benefit from the FAFSA-IRS link if the requirement were lifted that the applicant had already filed their 1040 for the most recent tax year. Alternatively, the FAFSA-IRS link could provide data from an earlier year's 1040. For example, a student applying in early 2012 for aid for 2012-13 could use IRS data from tax year 2010 (rather than 2011) to complete her FAFSA. These data could be used to determine her final 
aid eligibility, or as a placeholder until the 1040 is filed for 2011 . The latter is effectively what happens now: most applicants will complete their 2012-13 FAFSA before filing their 2011 taxes, providing estimates of their 2011 tax data in their FAFSA application. They are then required to update their FAFSA once they file for the 2011 tax year.

As it stands, however, families manually enter these estimates. ED could instead port from IRS the 2010 tax data, which would serve as an estimate of the 2011 values. Applicants who are confident that their 2011 tax data will differ substantially from the 2010 values can choose to manually enter their information. As they do now, families would then receive an estimate of their aid eligibility based on the 2010 tax return. ED and IRS could automatically update these values when the 2011 tax form is filed, just as the individual applicant now does. While these may sound like minor administrative tweaks, these minor tweaks open the possibility of a nearly automatic aid application. As Kahneman and Tversky (2000) and Thaler and Sunstein (2008) argue, small differences in administrative requirements can produce enormous differences in outcomes.

This approach still leaves some uncertainty in final aid eligibility (though no more than currently exists), since aid may be changed once the 2011 tax form is filed. An alternative that would allow for both simplicity and certainty in the aid process would be to determine final aid eligibility based on the previous year's 1040 . As we now show, this has little impact on the targeting of aid while increasing its simplicity and certainty.

In this analysis, we compare aid eligibility based on income from two adjacent tax years. For this exercise, we need to observe income in two consecutive years for a set of students. About half of the students in NPSAS who apply for aid for 2007-08 also apply for the following 
year. ${ }^{11}$ We estimate 2008-09 aid amounts using the methodology described earlier, first using all of the elements in the aid formula and then just the subset of items available in the IRS data. We then replace the IRS data items that were reported on the 2008-09 FAFSA with those reported on the 2007-08 FAFSA. This simulates the effect of allowing 2008-09 applicants to use data from the 1040 they filed in 2007 (for the 2006 tax year), rather than from the 1040 they will eventually file in 2008 (for the 2007 tax year).

Table 4 shows the results. In Column 1 we show the baseline aid for this group of repeat filers for the 2008-2009 school year. Here, aid eligibility is calculated using the full FAFSA, which includes items gathered from the applicant's 1040 for the 2007 tax year. In Column 2, we replace data from the 2007 tax year with data from the 2006 tax year. ${ }^{12}$ This simulates the effect of keeping all of the current FAFSA items while allowing all applicants to use the IRS-FAFSA link. The average Pell rises by $\$ 87$, or four percent, while overall Pell expenditures for this population rise by $\$ 300$ million. For 77 percent of applicants, the Pell remains within $\$ 500$ of baseline. For 67 percent of applicants, and 44 percent of Pell recipients, the Pell does not change at all. These changes are plotted against income (from the 2007 tax year) in Figure 6.

In Column 3 we examine the effect of eliminating all of the FAFSA items except for the 2007 tax data. For this sample of repeat applicants (as was true for the full sample), restricting the aid formula to IRS data has little effect on aid eligibility, with 72 percent of applicants seeing zero change in their Pell eligibility and 87 percent seeing a change of less than $\$ 500$. When we

\footnotetext{
${ }^{11}$ Ideally, we would undertake this exercise for all students, and not just those who attend for two consecutive years. This would be possible if the 2007-08 NPSAS were matched with tax returns for the 2006 and 2005 tax years. Aid for 2007-08 could then be calculated using the "prior year" tax data from 2006 as well as with the "prior-prior year" tax data from 2005. ${ }^{12}$ We inflate these 2006 dollar values to 2007 values using the CPI, which was 2.8 percent between these two years. This prevents a mechanical increase in aid eligibility induced by inflation.
} 
replace the 2007 IRS data with data from one year earlier, the results change only slightly (Column 4), with 65 percent of applicants now seeing zero change in their Pell eligibility and 74 percent seeing a change of less than $\$ 500$. The average Pell for this group rises to $\$ 2,070$, from a baseline of \$1,941 (Column 1). Average changes are plotted against (2007) income in Figure 7. Pell spending for this population rises by $\$ 400$ million, or a bit less than 7 percent, from its 200809 baseline of $\$ 6$ billion. These figures indicate that the price of an application-free Pell is a 7 percent increase in expenditures. This number, while not inconsequential, is dwarfed by recent increases in Pell generosity.

\section{Conclusion}

In 2006, Dynarski and Scott-Clayton hypothesized that complexity in the federal aid program was a barrier to college attendance. That paper also showed that the overwhelming majority of that complexity did nothing to improve targeting in the Pell Grant. Today, we know that complexity in the aid program is a barrier to college attendance. The FAFSA field experiment (Bettinger et al., forthcoming) showed conclusively that a drastically simplified aid application process increases college attendance. In this experiment, the effect of a simplified application on college attendance rates was comparable to that of offering an applicant thousands of dollars in grant aid. Based on these results and a review of other interventions intended to increase college attendance, Dynarski, Hyman, and Schanzenbach (2011) calculate that simplifying the aid process is (by several orders of magnitude) the cheapest way to increase college attendance.

In the face of this evidence, has the aid application process been simplified? There have been some successes. The user experience for the online FAFSA has been improved, with fewer repetitive questions and better skip logic. Online applicants are now offered an estimate of their 
Pell and Stafford eligibility, a major improvement over the past, when only the EFC was provided. In a major break through a longstanding administrative logjam, some applicants can now transfer their IRS tax data directly into their FAFSA from the IRS servers. All of these steps required sustained administrative energy and attention.

On the downside, the basic structure of the aid application process is unchanged. Applicants are still faced with a blizzard of paperwork. The FAFSA is just about as long and complicated as it was in 2006. For every two questions trimmed from the FAFSA, one more question has been added. As a result the FAFSA has shrunk only slightly (from 127 to 116 questions), and is still longer than the tax forms completed by most taxpayers. The online FAFSA, even with its improved user interface, involves 19 screens and just as many questions as the paper FAFSA. The IRS-FAFSA link, which has great potential to simplify the aid process, is hobbled by so many restrictions on its use that only 24 percent of applicants actually use it.

While there has been desultory progress in simplifying the aid system, the generosity and size of the Pell program have grown by leaps and bounds. Pell spending grew by $\$ 15$ billion between 2007-08 and 2009-10 and was estimated to grow by another $\$ 5$ billion by the end of 2010-11 (College Board, 2011). Drastic change has occurred in the generosity of the Pell program, which throws into even sharper relief the halting progress in reducing the program's complexity. A fraction of the dollars spent increasing the Pell maximum could be used to drastically simplify the aid process, thereby making the dollars that are already being spent more effective in increasing college attendance. We spend tens of billions of dollars on federal student aid, and the bill is rising rapidly. Simplifying student aid is a "last-mile" reform that costs little but requires sustained political and administrative attention. 


\section{Data Appendix}

We use individual-level data from the restricted-use version of the 2007-08 National

Postsecondary Student Aid Survey (NPSAS). NPSAS is representative of students filing for aid for the 2007-08 school year. A subset of students also files a FAFSA for 2008-09, and we limit the sample to this subset where indicated.

The NPSAS:08 includes FAFSA and financial aid data for 75,710 (11,199,083 surveyweighted) undergraduate federal aid applicants. We limit the sample to $35,810(4,951,822$ survey-weighted) students enrolled in one institution full-time for the full year during the 200708 academic year. From this sample, 890 (138,858 survey-weighted) students were dropped because they are missing EFC or data elements needed to calculate EFC. This leaves a sample of 34,920 (4,812,964 survey-weighted) undergraduate federal aid applicants for 2007-08. About half of these students filed a FAFSA for both the 2007-08 and 2008-09 academic years. For analyses in which we examine the reliability of older data for estimating aid, this yields a sample of 20,280 (3,079,184 survey-weighted) students.

In Figures 3-7, we plot aid values against income. For these graphs, the sample is divided into twenty intervals. Each interval contains 3 to 6 percent of the sample, except for the top interval (over $\$ 80,000$ ), which contains a quarter of the sample. 


\section{References}

Advisory Committee on Student Financial Assistance, 2005. The Student Aid Gauntlet: Making Access to College Simple and Certain: Final Report of the Special Study of Simplification of Need Analysis and Application for Title IV Aid. Advisory Committee on Student Financial Assistance, Washington, DC.

Bettinger, Eric P., Bridget Terry Long, Philip Oreopoulos, and Lisa Sanbonmatsu, forthcoming. "The Role of Simplification and Information in College Decisions: Results From the H\&R Block FAFSA Experiment.” Quarterly Journal of Economics.

Blumenthal, Marshal, and Joel Slemrod, 1992. "The Compliance Cost of the U.S Individual Income Tax System: A Second Look After Tax Reform.” National Tax Journal 45 (2), 185-202.

College Board, 2011. Trends in Student Aid: 2011. College Board, Washington, DC.

Commission on the Future of Higher Education, 2006. A Test of Leadership: Charting the Future of U.S. Higher Education. U.S. Department of Education, Washington, DC.

Council of Economic Advisors, 2009. Simplifying Student Aid: The Case for an Easier, Faster, and More Accurate FAFSA. Council of Economic Advisers, Washington, DC.

Duffy, Elizabeth, and Idana Goldberg, 1998. Crafting a Class: College Admissions and Financial Aid, 1955-1994. Princeton University Press, Princeton, NJ.

Dynarski, Susan, and Judith Scott-Clayton, 2006. "The Cost of Complexity in Federal Student Aid: Lessons from Optimal Tax Theory and Behavioral Economics.” National Tax Journal 59 (2), 319-356.

Dynarski, Susan, and Judith Scott-Clayton, 2007. “College Grants on a Postcard: A Proposal for Simple and Predictable Federal Student Aid.” Discussion Paper 2007-01. The Hamilton Project, Washington, DC.

Dynarski, Susan, Joshua Hyman, and Diane Schanzenbach, 2011. "Experimental Evidence on the Effect of Childhood Investments on Postsecondary Attainment and Degree Completion.” NBER Working Paper 17533. National Bureau of Economic Research, Cambridge, MA.

Institute of Education Sciences, 2011. Digest of Education Statistics: 2011. U.S. Department of Education, Washington, DC.

Kahneman, Daniel, and Amos Tversky, 2000. Choices, Values, and Frames. Cambridge University Press, Cambridge, MA.

Madrian, Brigitte C., and Dennis F. Shea, 2001. “The Power of Suggestion: Inertia in 401(k) 
Participation and Savings Behavior.” Quarterly Journal of Economics 116 (4), 11491187.

Parisi, Michael, 2011. "Individual Income Tax Returns, Preliminary Data, 2009.” Statistics of Income Bulletin (Winter), 7-21.

Rethinking Student Aid Study Group, 2008. Fulfilling the Commitment: Recommendations for Reforming Federal Student Aid. College Board, Washington, DC.

Steinberg, Jacquest, 2011. "Seeking Your Questions on the FAFSA, the Free Application for Federal Student Aid - NYTimes.com,” Retrieved January 7, 2011 at http://thechoice.blogs.nytimes.com/2012/01/06/mark-kantrowitz/.

Thaler, Richard, and Cass Sunstein, 2008. Nudge: Improving Decisions About Health, Wealth, and Happiness. Yale University Press, New Haven, CT.

U.S. Department of Education, 2008a. Summary of Changes for the Application Processing System: 2009-2010. U.S. Department of Education, Washington, DC.

U.S. Department of Education, 2008b. 2006-2007 Federal Pell Grant Program End-of-Year Report, U.S. Department of Education, Washington, DC.

U.S. Department of Education, 2009a. Federal Pell Grant Program End-of-Year Report, US. Department of Education, Washington, DC.

U.S. Department of Education, 2009b. "2007-2008 National Postsecondary Student Aid Survey: Restricted-Use Data File.” U.S. Department of Education, Washington, DC.

U.S. Department of Education, 2010. Summary of Changes for the Application Processing System: 2011-2012. U.S. Department of Education, Washington, DC.

U.S. Department of Education, 2011a. 2009-2010 Federal Pell Grant Program End-of-Year Report. U.S. Department of Education, Washington, DC.

U.S. Department of Education, 2011b. Federal Student Aid Application: Facts and Figures. U.S. Department of Education, Washington, DC.

Wilkinson, Rupert, 2005. Aiding Students, Buying Students. Vanderbilt University Press, Nashville, TN. 
Table 1

Complexity of IRS Tax Forms versus FAFSA

\begin{tabular}{|c|c|c|c|c|c|}
\hline & $\begin{array}{l}1040 \\
2010 \\
\end{array}$ & $\begin{array}{l}1040 \mathrm{~A} \\
2010 \\
\end{array}$ & $\begin{array}{l}\text { 1040EZ } \\
2010 \\
\end{array}$ & $\begin{array}{l}\text { FAFSA } \\
2006-2007 \\
\end{array}$ & $\begin{array}{l}\text { FAFSA } \\
2011-2012 \\
\end{array}$ \\
\hline $\begin{array}{l}\text { Number of pages (excluding } \\
\text { instructions) }\end{array}$ & 2 & 2 & 1 & 5 & 6 \\
\hline $\begin{array}{l}\text { Number of questions } \\
\text { Answered through IRS data link }\end{array}$ & 126 & 84 & 38 & 127 & $\begin{array}{l}116 \\
18\end{array}$ \\
\hline $\begin{array}{l}\text { Non-financial items } \\
\text { Identifying information } \\
\text { Demographic/family information } \\
\text { Enrollment status/school } \\
\text { Signature and preparer } \\
\text { Other }\end{array}$ & $\begin{array}{l}6 \\
8 \\
0 \\
12 \\
1\end{array}$ & $\begin{array}{l}6 \\
8 \\
0 \\
12 \\
1\end{array}$ & $\begin{array}{l}6 \\
2 \\
0 \\
12 \\
1\end{array}$ & $\begin{array}{l}22 \\
18 \\
7 \\
8 \\
10\end{array}$ & $\begin{array}{l}24 \\
29 \\
4 \\
8 \\
7\end{array}$ \\
\hline $\begin{array}{l}\text { Financial items } \\
\text { Earned income } \\
\text { Other income } \\
\text { Assets } \\
\text { Deductions/credits/allowances } \\
\text { Calculations from tables } \\
\text { Withholdings, refund preferences }\end{array}$ & $\begin{array}{l}1 \\
19 \\
0 \\
42 \\
21 \\
16\end{array}$ & $\begin{array}{l}1 \\
12 \\
0 \\
23 \\
12 \\
9\end{array}$ & $\begin{array}{l}1 \\
2 \\
0 \\
3 \\
6 \\
5\end{array}$ & $\begin{array}{l}5 \\
33 \\
6 \\
12 \\
6 \\
0\end{array}$ & $\begin{array}{l}5 \\
19 \\
6 \\
14 \\
0 \\
0\end{array}$ \\
\hline $\begin{array}{l}\text { Number of items required for } \\
\text { computation of tax or aid }\end{array}$ & 76 & 44 & 9 & 72 & 66 \\
\hline Number words in signing statement & 49 & 64 & 59 & 232 & 232 \\
\hline $\begin{array}{l}\text { Official estimate of hours to prepare } \\
\text { Paper } \\
\text { Web }\end{array}$ & 23 & 9 & 7 & 1 & $\begin{array}{l}3 \\
1\end{array}$ \\
\hline
\end{tabular}




\section{Table 2}

How Aid Formula Changes Have Affected Pell Grant Targeting Predicted Values for 2007-2008 Undergraduate Aid Applicants

\begin{tabular}{|c|c|c|c|c|}
\hline & $\begin{array}{l}2003-2004 \\
(1)\end{array}$ & $\begin{array}{l}2007-2008 \\
\text { Baseline } \\
(2)\end{array}$ & $\begin{array}{l}2009-2010 \\
\text { (3) }\end{array}$ & $\begin{array}{l}\text { 2011-2012 } \\
\text { (4) }\end{array}$ \\
\hline Correlation with baseline Pell & 0.978 & 1.00 & 0.950 & 0.922 \\
\hline $\mathrm{R}^{2}$ & 0.956 & 1.00 & 0.902 & 0.850 \\
\hline \multicolumn{5}{|l|}{ Share of applicants whose Pell } \\
\hline ...is within $\$ 100$ of baseline & 0.52 & 1.00 & 0.45 & 0.41 \\
\hline ...is within $\$ 500$ of baseline & 0.80 & 1.00 & 0.45 & 0.41 \\
\hline ...increases by $\$ 500$ or more & 0.00 & 0.00 & 0.55 & 0.59 \\
\hline ...decreases by $\$ 500$ or more & 0.20 & 0.00 & 0.00 & 0.00 \\
\hline Share with automatic zero EFC & 0.10 & 0.17 & 0.22 & 0.22 \\
\hline Average Pell (\$, includes zeroes) & 1,417 & 1,673 & 2,443 & 2,692 \\
\hline Total Pell (\$billion) & 6.8 & 8.1 & 11.8 & 13.0 \\
\hline Share Pell recipients & 0.45 & 0.48 & 0.55 & 0.59 \\
\hline Pell maximum (\$) & 4,050 & 4,310 & 5,350 & 5,550 \\
\hline
\end{tabular}

Notes: Sample consists of 34,920 undergraduate aid applicants enrolled at one institution for a full year during 2007-2008 academic year. Students' characteristics are run through aid formula for listed years to predict aid values. See Data Appendix for details. Analysis uses NPSAS weights (WTA000). Source: NPSAS:08. 
Table 3

Effect of Aid Formula Simplification on Distribution of Pell

\begin{tabular}{|c|c|c|}
\hline & $\begin{array}{l}2007-2008 \\
\text { Full FAFSA } \\
(1)\end{array}$ & $\begin{array}{l}2007-2008 \\
\text { IRS Data Only } \\
(2)\end{array}$ \\
\hline Correlation with baseline Pell & 1.00 & 0.947 \\
\hline $\mathrm{R}^{2}$ & 1.00 & 0.896 \\
\hline \multicolumn{3}{|l|}{ Share of applicants whose Pell } \\
\hline ...does not change & 1.00 & 0.73 \\
\hline ...is within $\$ 100$ of baseline & 1.00 & 0.78 \\
\hline ...is within $\$ 500$ of baseline & 1.00 & 0.88 \\
\hline ....increases by $\$ 500$ or more & & 0.07 \\
\hline ...decreases by $\$ 500$ or more & & 0.04 \\
\hline Average Pell (\$, includes zeroes) & 1,673 & 1,746 \\
\hline Total Pell (\$billion) & 8.1 & 8.4 \\
\hline Share Pell recipients & 0.48 & 0.49 \\
\hline Items required for calculation of aid & 74 & 8 \\
\hline
\end{tabular}

Notes: See Table 2. 


\section{Table 4}

How Does Using Older Income Data Affect Pell Eligibility? Estimates of 2008-09 Aid Using IRS Data From 2007 versus 2006

\begin{tabular}{|c|c|c|c|c|}
\hline & \multirow{3}{*}{$\begin{array}{l}\text { Full FAFSA } \\
2007 \text { Tax } \\
\text { Data } \\
\text { (1) }\end{array}$} & \multirow{3}{*}{$\begin{array}{l}\text { Full FAFSA } \\
2006 \text { Tax } \\
\text { Data } \\
\text { (2) }\end{array}$} & \multirow{3}{*}{$\begin{array}{l}\text { No FAFSA } \\
2007 \text { Tax } \\
\text { Data } \\
\text { (3) }\end{array}$} & \multirow{3}{*}{$\begin{array}{l}\text { No FAFSA } \\
2006 \text { Tax } \\
\text { Data } \\
\text { (4) }\end{array}$} \\
\hline & & & & \\
\hline & & & & \\
\hline Correlation with baseline Pell & 1.00 & 0.858 & 0.951 & 0.837 \\
\hline $\mathrm{R}^{2}$ & 1.00 & 0.736 & 0.905 & 0.700 \\
\hline \multicolumn{5}{|l|}{ Share of applicants whose Pell } \\
\hline ...does not change & 1.00 & 0.67 & 0.72 & 0.65 \\
\hline ...is within $\$ 100$ of baseline & 1.00 & 0.70 & 0.76 & 0.67 \\
\hline ...is within $\$ 500$ of baseline & 1.00 & 0.77 & 0.87 & 0.74 \\
\hline ...increases by $\$ 500$ or more & 0.00 & 0.14 & 0.07 & 0.16 \\
\hline ...decreases by $\$ 500$ or more & 0.00 & 0.09 & 0.06 & 0.10 \\
\hline Average Pell (\$, includes zeroes) & 1,941 & 2,028 & 1,984 & 2,070 \\
\hline Total Pell (\$billion) & 6.0 & 6.3 & 6.1 & 6.4 \\
\hline Share Pell recipients & 0.50 & 0.52 & 0.50 & 0.52 \\
\hline Items required for calculation of aid & 74 & 74 & 8 & 8 \\
\hline
\end{tabular}

Notes: Sample consists of 20,280 aid applicants who filed a FAFSA in both 2007-2008 and 2008-2009. See Data Appendix for details. Simulation in Column 2 uses the same elements as Column 1 but uses 2006 instead of 2007 tax information (AGI, earned income, taxes paid, type of income tax form used). Simulations in Columns 3 and 4 drop the FAFSA and use only IRS data for the listed tax years. 2006 tax values are inflated to 2007 values using Consumer Price Index for All Urban Consumers (CPI-U). 
Figure 1

Month of FAFSA Submission for 2007-08 Applicants

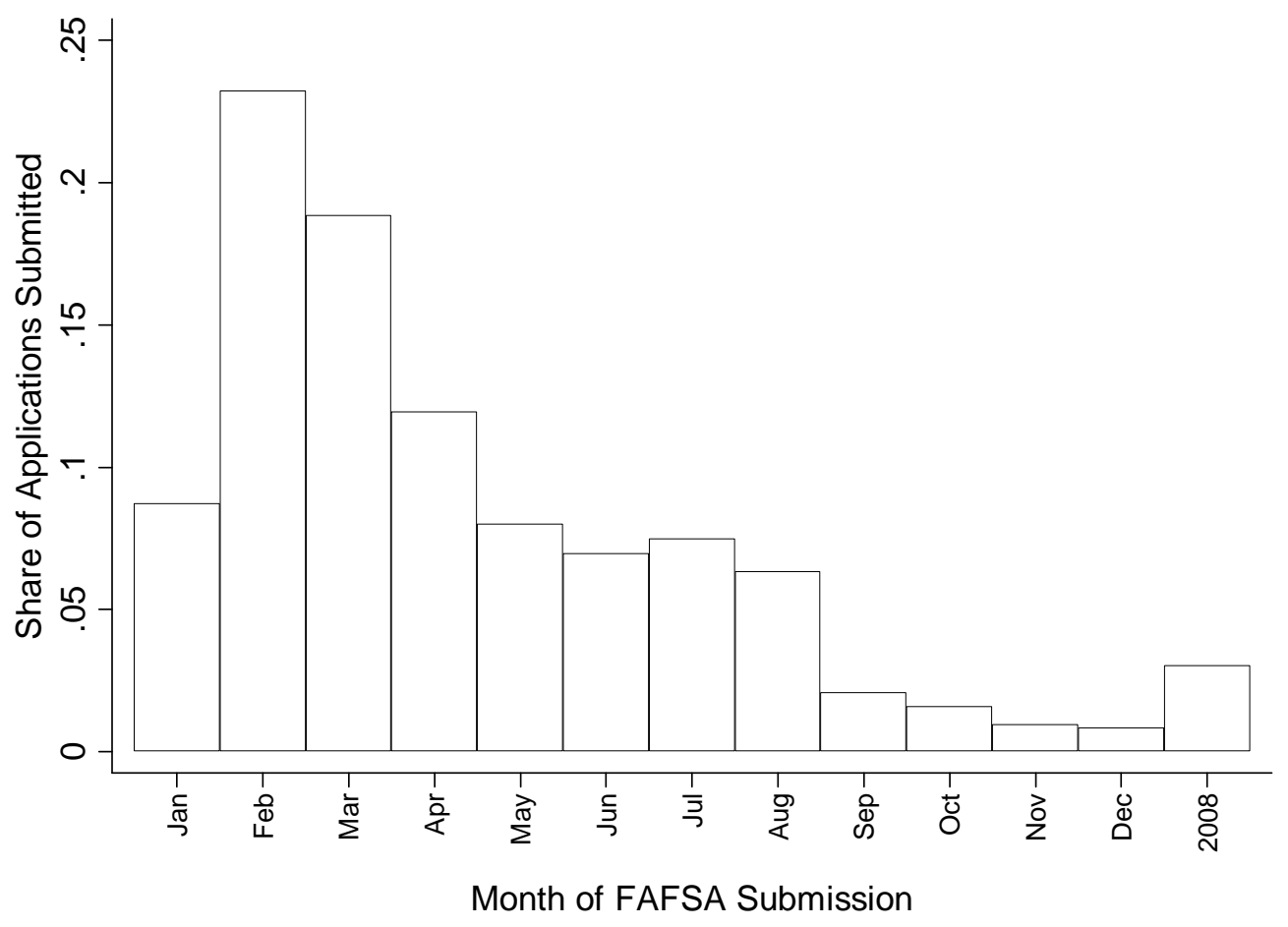

Notes: See Data Appendix for sample definition. 


\section{Figure 2}

\section{Pell Enrollment and Expenditures, Relative to 1976-1977 Levels Constant 2010 Dollars}

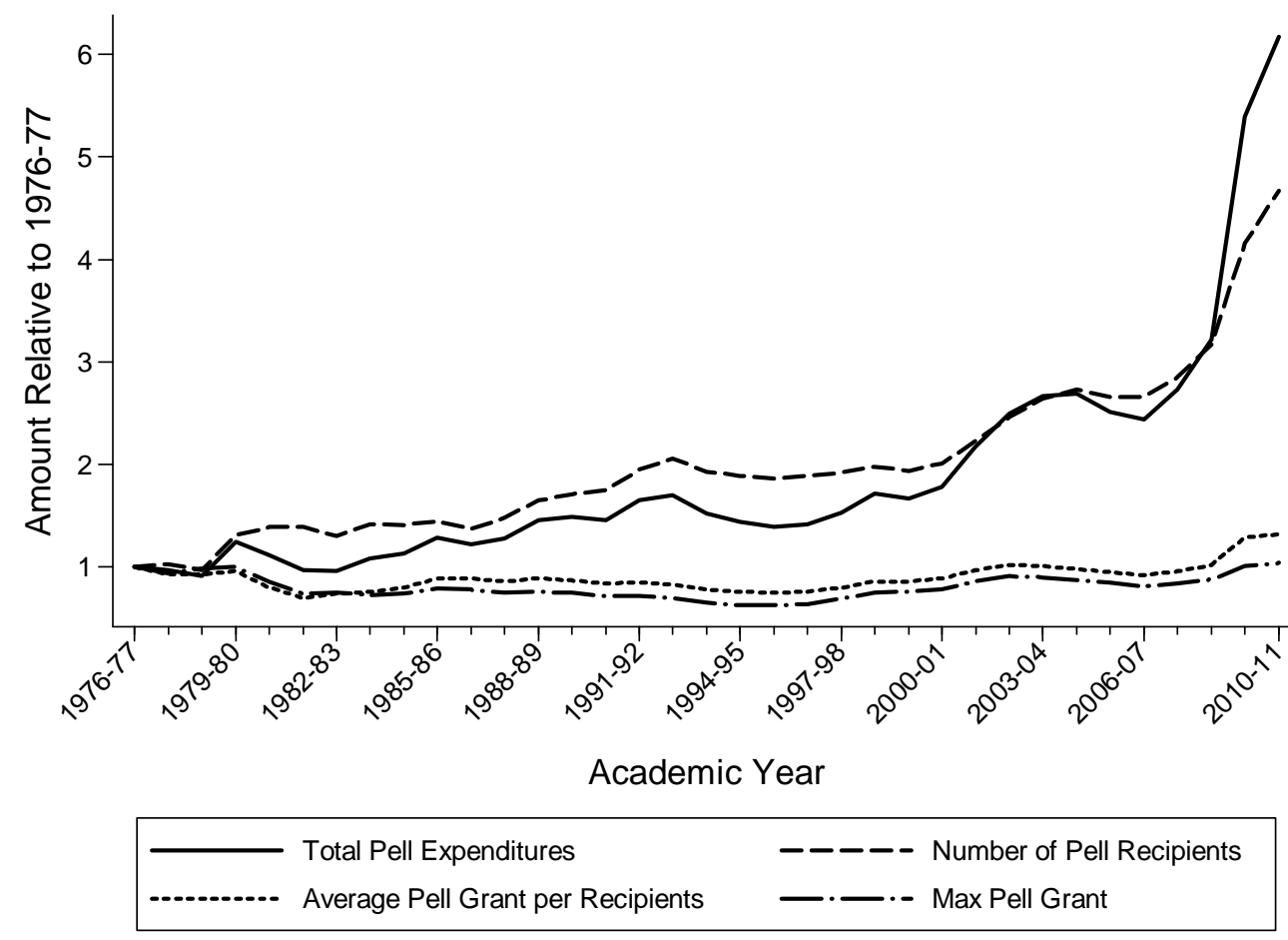

Source: College Board (2011), Figure 13A. 


\section{Figure 3}

Increasing Generosity of the Pell Grant, by Year and Income

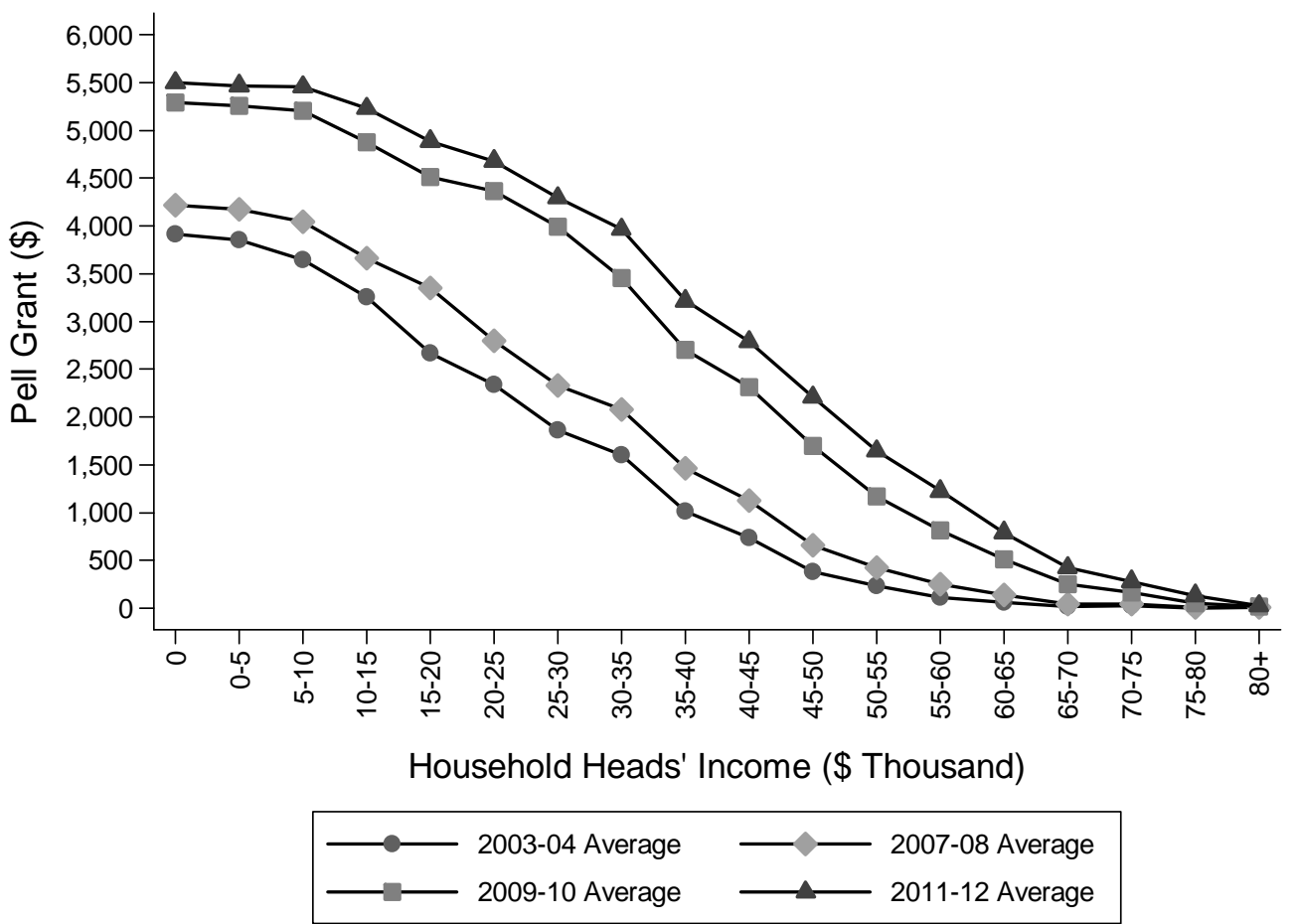

Notes: See notes to Table 2. 
Figure 4

Increases in Generosity of the Pell Grant from 2007-08 to 2011-12, by Income

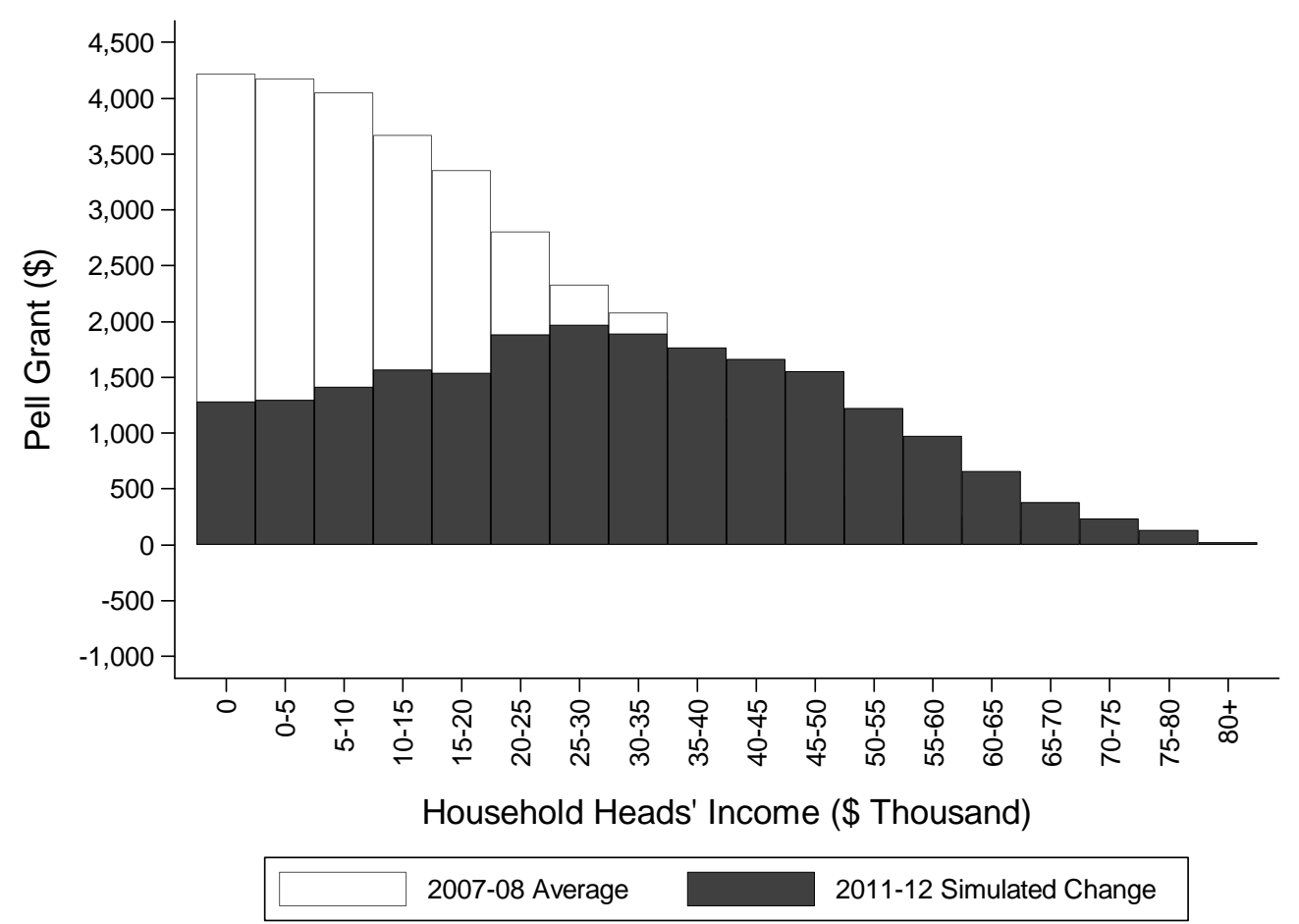

Notes: See notes to Table 2. 


\section{Figure 5}

Effect of Using Only IRS Data to Define Pell Eligibility: 2007-2008 Aid Year

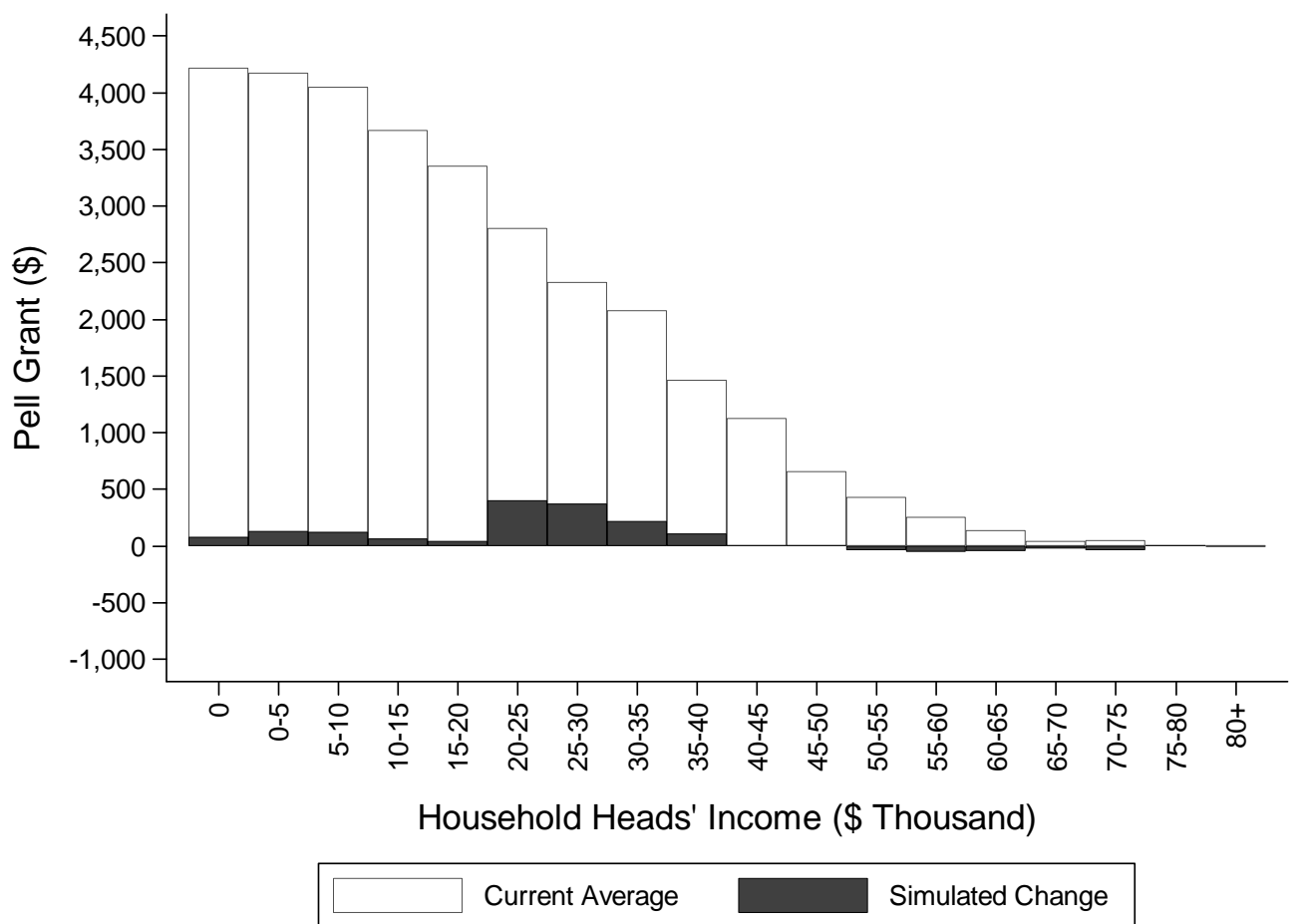

Notes: See notes to Table 3. 


\section{Figure 6}

Keep Current Formula, Allow All Applicants to Use IRS-FAFSA Link 2008-09 Aid Year

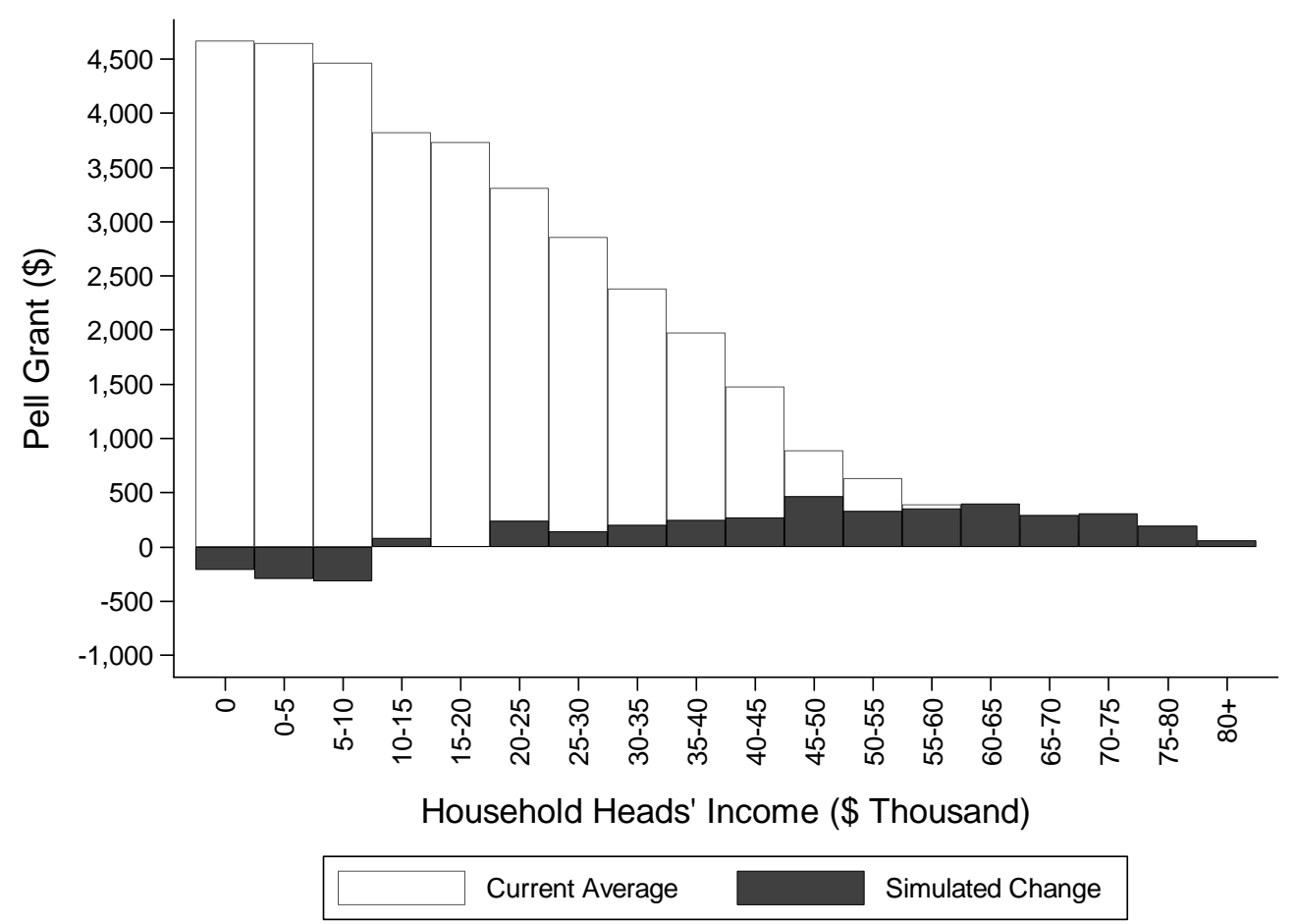

Notes: See notes to Table 4. Corresponds to simulation in Column 2. 


\section{Figure 7}

\section{Eliminate FAFSA, Use Older Tax Data to Compute Pell Eligibility 2008-09 Aid Year}

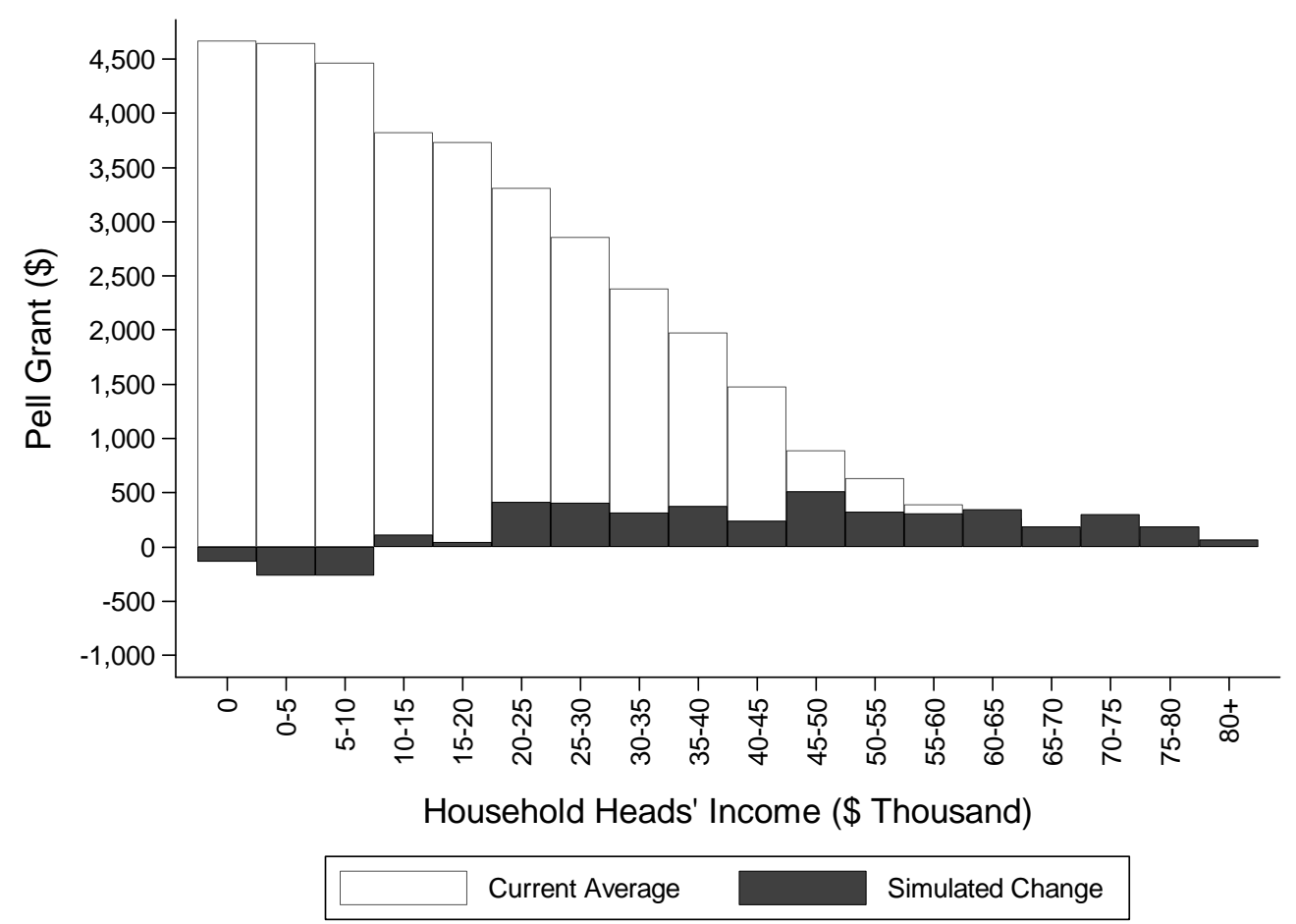

Notes: See notes to Table 4. Corresponds to simulation in Column 4. 